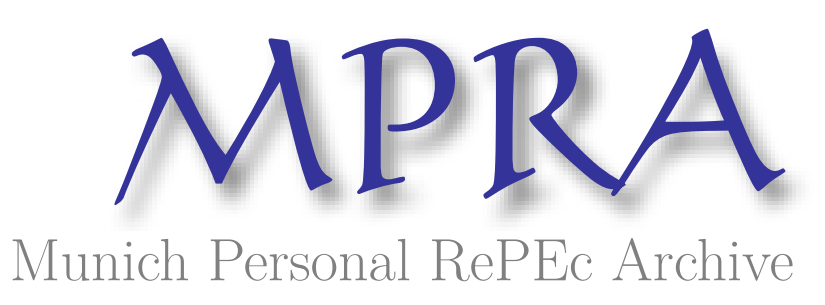

\title{
Structural Effects of a Real Exchange Rate Revaluation in China: A CGE Assessment
}

Willenbockel, Dirk

April 2006

Online at https://mpra.ub.uni-muenchen.de/920/

MPRA Paper No. 920, posted 25 Nov 2006 UTC 


\title{
Structural Effects of a Real Exchange Rate Revaluation in China:
}

\author{
A CGE Assessment
}

\author{
Dirk Willenbockel \\ Middlesex University Business School \\ London NW4 4BT - UK \\ From 10/2006: \\ Institute of Development Studies \\ University of Sussex \\ Brighton BN1 9RE - UK
}

\begin{abstract}
The misalignment of the Chinese currency exposed by the rapid build-up of China's foreign exchange reserves over the past few years has been the subject of considerable recent debate. Recent econometric studies suggest a Renminbi undervaluation on the order of 10 to 30\%. The modest revaluation of July 2005 is widely perceived as insufficient to correct China's balance-of-payments disequilibrium and has not silenced charges that China is engaging in persistent one-sided currency manipulation. Within China there are widespread concerns regarding the adverse employment effects of a major revaluation on labourintensive export sectors, yet the likely magnitude of these effects remains a controversial issue. The paper aims to shed light on this question by simulating the structural effects of a real exchange rate revaluation that lowers the current account surplus-GDP by 4 percentage-points using a 17-sector computable general equilibrium model of the Chinese economy.
\end{abstract}

April 2006

d.willenbockel@ids.ac.uk

Paper presented at International Conference on Policy Modeling - ECOMOD 2006, Hong Kong, July 2006. An earlier version of this paper has been presented at the Autumn Meeting of the Post Keynesian Economics Study Group 2005, Middlesex University Business School, London, November 2005. 


\section{Introduction}

The apparent misalignment of the Chinese currency associated with the simultaneous presence of persistent current account balance surpluses, substantial net foreign investment inflows and a rapid build-up of China's foreign exchange reserves over the past few years has been the subject of considerable recent policy debate and continues to be a controversial issue. Recent econometric studies suggest a Renminbi (RMB) undervaluation on the order of 10 to $30 \%$ over the last two to three years. ${ }^{1}$ Since 2003 , external political lobbying efforts pressing for a major RMB exchange rate realignment have steadily increased. Having kept a strict de facto peg to the US Dollar since mid1994, the People's Bank of China allowed an effective nominal 2.1\% revaluation of the RMB against the Dollar in July 2005. However, this modest revaluation is widely perceived as insufficient to correct China's balance-of-payments disequilibrium.

Demands for a more substantial RMB revaluation are not only raised by international voices, but also by internal observers who question the sustainability of the current misalignment situation and argue that a realignment is in China's own interest. On the other hand, there are widespread concerns within China regarding the potential adverse employment effects of a major revaluation on labour-intensive export sectors, yet the likely magnitude of these effects remains a controversial issue. ${ }^{2}$

The paper aims to shed light on this question by simulating the structural effects of a real exchange rate revaluation that lowers the current account surplus-GDP ratio by 4 percentage-points using a 17-sector computable general equilibrium of the Chinese economy and its trade relations with the rest of the world.

Section 2 provides necessary background information on the evolution of China's current account from 1990 to 2004 and the exchange rate policy of the People's Bank of China over the period. Section 3 describes the analytic model, the benchmark data set and the numerical calibration process. Section 4 details the implementation of a revaluation shock into the model and presents simulation results for alternative labour market closures, and section 5 draws conclusions.

\footnotetext{
${ }^{1}$ See Chang and Shao (2004), Funke and Rahn (2004, 2005), Goldstein (2004), Zhang and Pan (2004).

${ }^{2}$ See e.g. Tung and Baker (2004) and Sun and Ma (2005).
} 


\section{Developments in China's Balance of Payments}

Charts 1 and 2 display the development of China's current account and capital account balances and their main components from the early 1990s onwards. Primarily driven by movements in the trade balance, the current account has been persistently in surplus since 1994. Of particular interest in the present context is the strong increase of the current account balance over the last few years from 2001 onwards. In relation to the domestic product the current account rose from 1.5\% in 2001 to $4.0 \%$ of GDP in 2004.

Simultaneously, starting in 2001/2, the capital account of the balance of payments exhibits rapidly rising surpluses as shown in Chart 2 . These are not fueled by net inward FDI flows which have grown at a relatively moderate pace, but rather by portfolio investment and other investment inflows. In addition, there has been a sign reversal of the traditionally negative net errors and obmissions component since 2002 that indicates a capital flight reversal effect. These capital movements are clearly speculative in anticipation of a RMB appreciation. ${ }^{3}$ The capital account surplus reached $8 \%$ of GDP in 2004.

The combination of large and rising surpluses on both current and capital account since 2002 entails the rapid build-up of foreign exchange reserves reported in Chart 3. In 2004 the increase in foreign reserves amounted to a staggering 12\% of GDP. Despite these recent balance-of-payments developments that indicate the emergence of a significant RMB misalignment from 2002, the PBOC maintained the rigid de-facto peg of the RMB against the US Dollar it had kept since mid-1994. In July 2005, the PBOC allowed an effective nominal 2.1\% revaluation of the RMB against the Dollar and announced to define its exchange rate targets in terms of a trade-weighted currency basket in the future. ${ }^{4}$ However, this modest revaluation is widely perceived as insufficient to correct China's balance-of-payments disequilibrium and has not silenced charges that China is engaging in persistent one-sided currency manipulation. ${ }^{5}$

\footnotetext{
${ }^{3}$ See e.g. Huang and Wang (2004) and Blanchard and Giavazzi (2005).

${ }^{4}$ See e.g. Spiegel (2005).

${ }^{5}$ See in particular Goldstein and Lardy (2005a).
} 
Chart 1: China Mainland Current Account Components 1990-2004

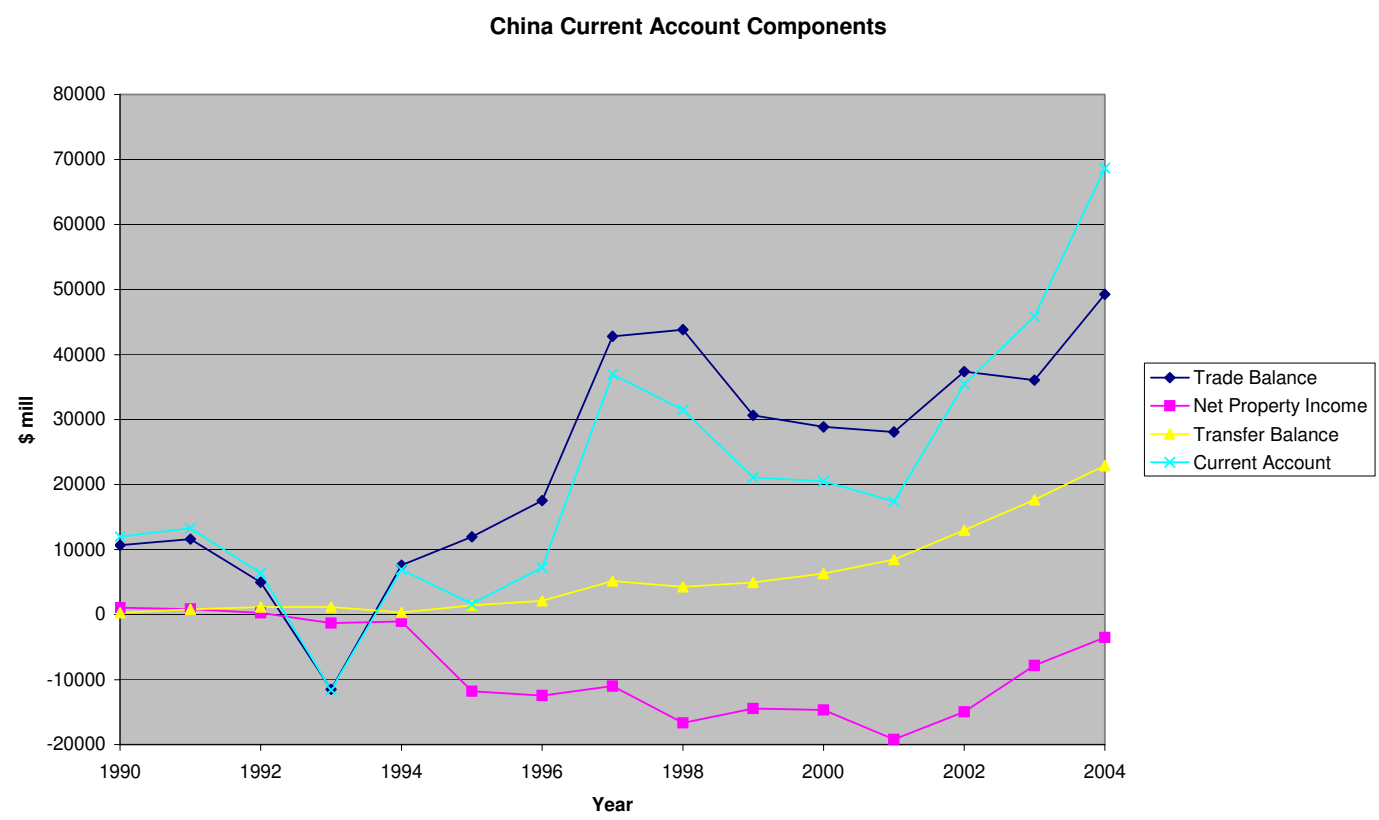

Data Source: IMF International Financial Statistics.

Note: Current account $=$ Trade balance + Net property income + Transfer balance

\section{Chart 2: China Mainland Capital Account Components 1990-2004}

Capital Account Components

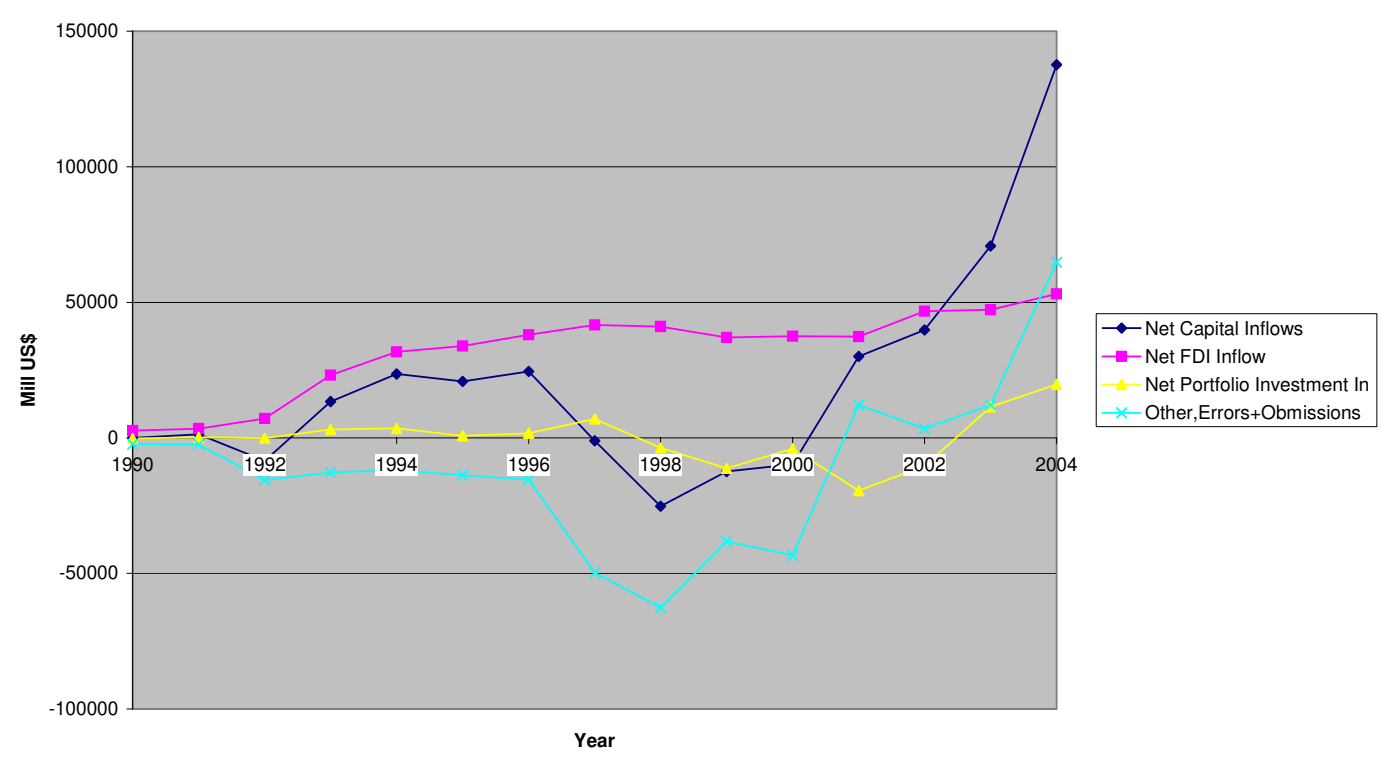

Data Source: IMF International Financial Statistics.

Note: Net capital inflows $=$ Net FDI inflow + Net portfolio investment inflow + Other, errors + obmissions 


\section{Chart 3: Change in Official Foreign Exchange Reserves China Mainland 1990-2004}

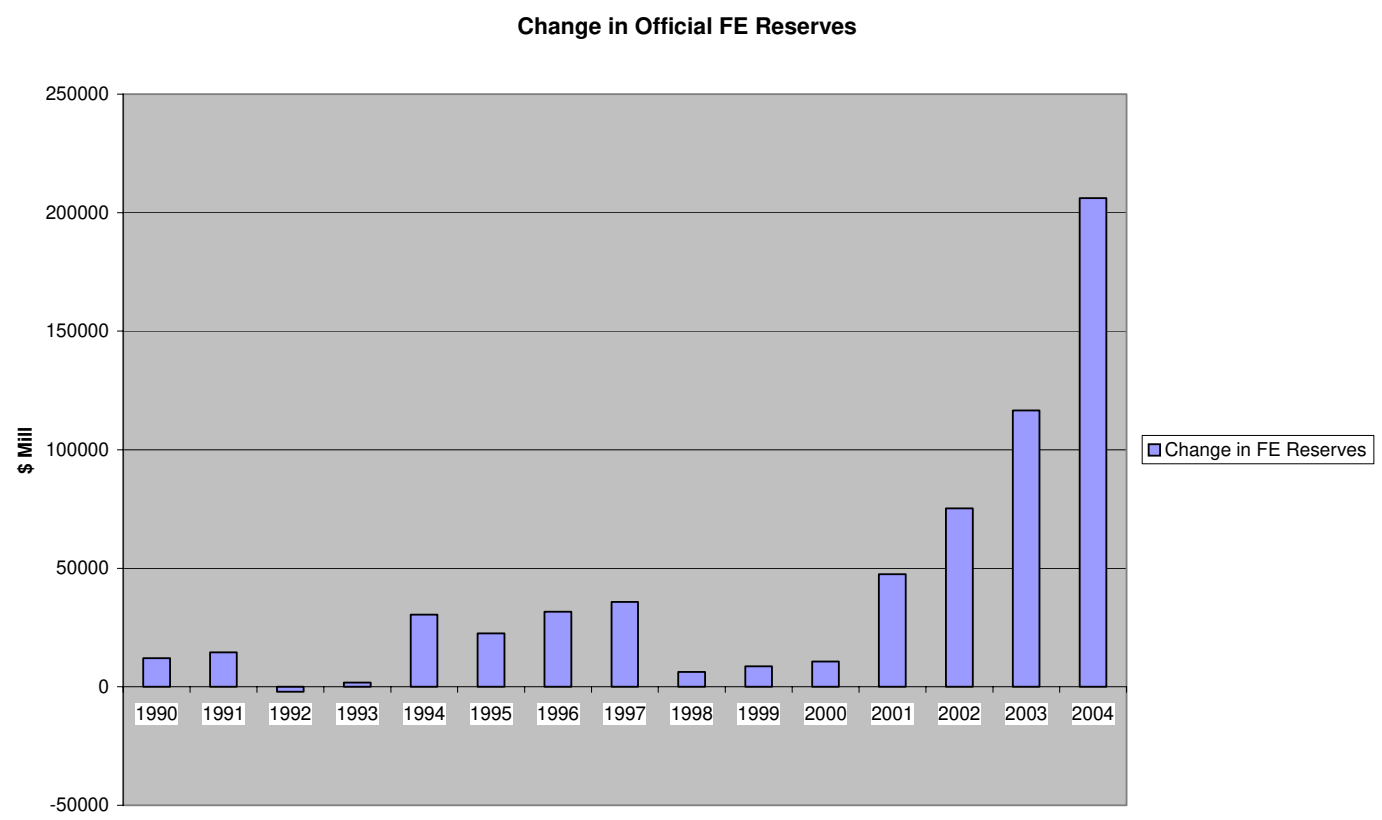

Data Source: IMF International Financial Statistics

In order to curb the potential inflationary consequences of its massive foreign exchange market interventions to defend the peg, the PBOC partially sterilizes its foreign reserve acquisitions by issuing central bank bills and bonds as well as through controls on bank lending. ${ }^{6}$ Despite these sterilization efforts, M1 grew by 19\% in 2003 and $15 \%$ in 2004 , while inflation as measured by the CPI rose from virtually nil in 2000 to $4 \%$ in 2000 .

As basic open-economy macroeconomic theory suggests, if the nominal exchange rate is not allowed to respond to the external imbalance, the required real revaluation is gradually enforced through a rise in the domestic price level. In short, apart from external political pressure, there is also rising internal economic pressure for a major realignment. ${ }^{7}$ Goldstein (2004) argues that a drop of the current-account/GDP ratio by around 4 percentage points is required to re-establish current balance-of-payments equilibrium.

\footnotetext{
${ }^{6}$ Compare Sun and Ma (2004), Goldberg (2004), Blanchard and Giavazzi (2005).

${ }^{7}$ In contrast, according to the controversial "revived Bretton Woods" hypothesis proposed by Dooley et al. (2003), the situation is interpreted as part of a medium-run-stable implicit contract between the USA and emerging Asian nations pursuing an export-led growth strategy. See Goldstein and Lardy (2005b) for a harsh verdict on this proposition and Dooley and Garber (2005) for further discussion.
} 
Below we employ a multisectoral computable general equilibrium model of the Chinese economy to simulate the structural effects and employment relocation effects associated with a real exchange rate revaluation that generated a drop in the trade balance of this magnitude.

\section{The Analytical Framework}

\section{The Model}

The analytic framework is a comparative-static computable general equilibrium model of China's economy and its trade relations with the rest of the world. The model distinguishes 17 industries / commodity groups as listed in Table 1 and the two sectorally mobile primary production factors labour and capital. In each commodity group except electricity supply, domestic output and imports are imperfect substitutes in demand. Let J denote an index set over industry / commodity groups. Total domestic demand for each commodity group $\mathrm{i}$ is modeled as demand for an Armington composite commodity

$Q_{i}=\left[\delta_{i} D_{i}^{\left(\sigma_{i}-1\right) / \sigma_{i}}+\left(1-\delta_{i}\right) M_{i}^{\left(\sigma_{i}-1\right) / \sigma_{i}}\right]^{\sigma_{i} /\left(\sigma_{i}-1\right)}$,

where $D_{i}$ denotes domestic demand for domestic output, $M_{i}$ denotes imports, and $\sigma_{i}$ is the elasticity of substitution between domestic and imported goods. Demand for $\mathrm{Q}_{i}$ is the sum of consumer demand $C_{i}$, investment demand $I_{i}$, government demand $G_{i}$ and intermediate input demand:

$Q_{i}=C_{i}+I_{i}+G_{i}+\sum_{j \in J} x_{i j}$

Faced with prices $\mathrm{P}_{\mathrm{i}}$ and $\mathrm{PM}_{\mathrm{i}}$ for goods of domestic origin and imports respectively, optimizing agents allocate their spending between home goods and imports such that

$D_{i}=\delta_{i}^{\sigma_{i}}\left[\frac{P_{i}}{\theta_{i}}\right]^{-\sigma} Q_{i} \quad, \quad M_{i}=(1-\delta)_{i}^{\sigma_{i}}\left[\frac{P M_{i}}{\theta_{i}}\right]^{-\sigma} Q_{i}$,

where

$\theta_{i}=\left[\delta_{i}^{\sigma_{i}} P_{i}^{1-\sigma_{i}}+\left(1-\delta_{i}\right)^{\sigma_{i}} P M_{i}^{1-\sigma_{i}}\right]^{1 /\left(1-\sigma_{i}\right)}$

is the true price index dual to the Armington quantity index (1).

Sectoral consumer demand functions are derived from a nested Stone-Geary-Armington utility function 
$U=\sum_{i \in J}\left(C_{i}-\beta_{i}\right)^{\alpha_{i}} \quad, \quad \alpha_{i} \geq 0, \sum_{i \in J} \alpha_{i}=1$

and take the LES (linear expenditure system) form

$C_{i}=\beta_{i}+\frac{\alpha_{i}}{\theta_{i}}\left(C H-\sum_{i \in J} \beta_{i} \theta_{i}\right)$

where $\mathrm{CH}$ denotes total household consumption expenditure.

Investment demand by commodity group obeys

$I_{i}=k_{i} I N V / \theta_{i}, \sum_{i \in J} k_{i}=1$,

where INV denotes total nominal investment spending.

The vector of real government spending by commodity group, $\mathrm{G}_{\mathrm{i}}$, is exogenous and kept fixed in the simulation exercises reported below.

On the domestic supply side, firms are price takers in output and input markets. Technologies in all sectors are characterized by constant returns to scale, imperfect primary factor substitutability, and imperfect substitutability between domestic and imported intermediate inputs in the same commodity group. Sectoral production functions take the Leontief-CES form

$$
X_{i}=\min \left[V_{i}\left(K_{i}, L_{i}\right),\left.\frac{x_{j i}}{a_{j i}}\right|_{\forall j \in I}\right],
$$

where $\mathrm{X}_{\mathrm{i}}$ denotes gross output, $\mathrm{x}_{\mathrm{ji}}$ denotes intermediate input consumption of commodity type $\mathrm{j}$ by industry $\mathrm{i}$, and

$V_{i}=\gamma_{i}\left[\phi_{L, i} L_{i}^{-\rho}+\phi_{K, i} K_{i}^{-\rho}\right]^{-1 / \rho}, \quad \rho \geq-1$

is the value-added production function, where $\mathrm{L}_{\mathrm{i}}$ and $\mathrm{K}_{\mathrm{i}}$ represent labour and capital inputs respectively. Cost minimization yields the unit factor demand functions

$L_{i} / X_{i}=\gamma_{i}^{-1} \phi_{L, i}^{\varepsilon_{i}} w_{L}^{-\varepsilon_{i}} \cdot\left[\sum_{j \in\{L, K\}} \phi_{j}^{\varepsilon} w_{j}^{1-\varepsilon}\right]^{1 / \rho}, K_{i} / X_{i}=\gamma_{i}^{-1} \phi_{K, i}^{\varepsilon_{i}} w_{K}^{-\varepsilon_{i}} \cdot\left[\sum_{j \in\{L, K\}} \phi_{j}^{\varepsilon} w_{j}^{1-\varepsilon}\right]^{1 / \rho}$,

where $\varepsilon=1 /(1+\rho) \geq 0$ denotes the factor elasticity of substitution.

In analogy to the domestic demand side, China' exports to the rest of the world (RoW) are treated as imperfect substitutes for goods of RoW origin in RoW demand. In each commodity group, RoW demand for an Armington composite defined over goods of Chinese and RoW origin is assumed to be unitary-elastic. The optimal allocation of 
expenditure within each commodity group yields export demand functions for goods of Chinese origin of the form

$E_{i}=\kappa_{i} \delta_{R, i}^{\sigma_{R, i}} P E_{i}^{-\sigma_{r, i}} \theta_{R, i}^{\sigma_{R, i}-1}$,

where $\kappa_{\mathrm{i}}$ is RoW's total expenditure on type-i goods

$P E_{i}=P_{i}\left(1-\tau_{R, i}\right) / e$,

is the foreign-currency price of China's exports faced by users in the rest of the world inclusive of tariff equivalents of trade barriers $\tau_{\mathrm{R}}$ imposed on China's exports by the rest of the world, and

$\theta_{R, i}=\left[\delta_{R, i}^{\sigma_{R, i}} P E_{i}^{1-\sigma_{R, i}}+\left(1-\delta_{R, i}\right)^{\sigma_{R, i}} P M W_{i}^{1-\sigma_{R, i}}\right]^{1 /\left(1-\sigma_{R}\right)}$

are the price indices dual to the RoW Armington composites, where the $\mathrm{PMW}_{\mathrm{i}}$ are exogenously given prices of RoW goods ${ }^{8}$ and $\mathrm{e}$ is a conversion factor reflecting the relation between the domestic unit of account (i.e. the dimension in which nominal accounting prices $\mathrm{P}$ and $\mathrm{PM}$ are measured) and the foreign unit of account (i.e. the dimension in which PE and PMW are expressed). By running a trade balance surplus in the benchmark equilibrium, the domestic economy exchanges its current exports not only for current imports but partly for a foreign reserve asset issued by the RoW. A unit of this asset entitles to $1 / \mathrm{PMW}_{\mathrm{i}}$ units of any import good $\mathrm{i}$ at a later date and $\mathrm{e}$ is the nominal price per unit of this asset expressed in the domestic unit of account. ${ }^{9}$

The domestic user prices of imports are related to the fixed world market prices PMW via $P M_{i}=e \cdot P M W_{i}\left(1+\tau_{m, i}\right)$,

where $\tau_{\mathrm{m}}$ denotes import tariffs.

Equations (15) to (17) describe the macro closure of the model. Household savings SH are a fixed fraction of factor income $\mathrm{Y}$ and must equal the sum of the model government deficit $\mathrm{GD}^{10}$, investment spending INV and the trade balance $\mathrm{TB}=\mathrm{e}$ TBW. It is important to note that the TB component of savings reflects to a large extent private

\footnotetext{
${ }^{8}$ See Willenbockel (1994:118-121) for a more detailed discussion of the specification of export demand functions in single-region CGE models.

${ }^{9}$ Readers who wonder why I refrain from simply labeling e the "nominal exchange rate" are refered to Willenbockel (1994:53-54).

${ }^{10}$ Only sales taxes at ad valorem rates t $\mathrm{p}_{\mathrm{i}}$ and import taxes are explicitly captured in the model. Thus the part of SH used to "finance" GD comprises both tax payments not explicitly modeled and purchases of government debt instruments.
} 
sector purchases of central bank bills and sterilization bonds issued by the PBOC to sterilize the money supply impact of its foreign exchange market interventions.

$Y=w_{L} \sum_{i \in J} L_{i}+w_{K} K=C H+S H$,

$S H=s Y=G D+I N V+e T B W$,

$G D=\sum_{i \in J} \theta_{i} G_{i}-t p_{i} P_{i} X_{i}-\tau_{m, i} P M W_{i} M_{i}$.

Here purchases of the foreign reserve asset and the saving rate s are exogenous, while INV and GD are endogenously determined.

The product market clearing conditions are

$X_{i}=D_{i}+E_{i}$

and the factor market equilibrium conditions are

$\bar{K}=\sum_{i \in J} K_{i}$

$L=\sum_{i \in J} L_{i}$

where $\mathrm{L}$ and $\mathrm{K}$ denote the given factor endowments. The simulation exercises below also allow for the case of unlimited supplies of labour. In this case, the real wage $\mathrm{w}_{\mathrm{L}} / \mathrm{CPI}$ is kept fixed and $\mathrm{L}$ is endogenized.

\section{Data and Calibration}

The model is calibrated to the 17-industry input-output table for 2000 (China Statistical Office, 2004). Table 1 summarizes the main sectoral features. The somewhat idiosyncratic industry aggregation is dictated by the data source. Extraneous values for the Armington elasticities and the factor elasticities ofsubstitution are drawn from the GTAP behavioural parameter data base (Dimaranan et al., 2002).

The $\alpha$ parameters in (6) are calibrated to extraneous information on sectoral income elasticities of demand $\varepsilon$ for China drawn from Huff et al. (1997):

$\varepsilon_{i}=\frac{\alpha_{i} C H}{\theta_{i} C_{i}}=\alpha_{i} / s_{i} \Rightarrow \alpha_{i}=\varepsilon_{i} s_{i}, s_{i} \equiv \frac{\theta_{i} C_{i}}{C H}$.

The extraneous income elasticity have been re-scaled prior to calibration to enforce the Engel aggregation condition $\sum \mathrm{s}_{\mathrm{i}} \varepsilon_{\mathrm{i}}{ }^{\mathrm{Y}}=1$. The $\beta$ parameters are determined by choosing a 
value for the Frisch parameter $\Omega=-\mathrm{CH} /\left(\mathrm{CH}-\sum \beta_{\mathrm{i}} \theta_{\mathrm{i}}\right)<0$ which represents the elasticity of the marginal utility of income with respect to income. (6) entails the calibration rule $\beta_{i}=C_{i}+\frac{\alpha_{i} C H}{\theta_{i} \Omega}$.

Note that for given $\alpha$, the choice of $\Omega$ determines the whole set of benchmark own- and cross-price elasticities of consumer demand which are given by $\frac{\partial \ln C_{i}}{\partial \ln \theta_{i}}=-1+\frac{\beta_{i}\left(1-\alpha_{i}\right)}{C_{i}}, \frac{\partial \ln C_{i}}{\partial \ln \theta_{j \neq i}}=-\alpha_{i} \frac{\theta_{j} \beta_{j}}{\theta_{i} C_{i}}$.

The benchmark own-price elasticities implied by the calibrated values of $\alpha$ and $\beta$ are reported along with the Armington elasticities, income elasticities and labour-capital substitution elasticities in Table 2 . 
Table 1: Sectoral Employment and Trade Structure China 2000

\begin{tabular}{|c|c|c|c|c|c|}
\hline Sector & $\begin{array}{c}\text { Employment } \\
\text { Share } \\
\% \\
\end{array}$ & $\begin{array}{c}\text { Export } \\
\text { Share } \\
\%\end{array}$ & $\begin{array}{c}\text { Import Share } \\
\%\end{array}$ & $\begin{array}{c}\text { Labour - } \\
\text { Capital Ratio }\end{array}$ & $\begin{array}{c}\text { Export - } \\
\text { Output } \\
\text { Ratio \% }\end{array}$ \\
\hline Agriculture & 26.93 & 2.52 & 2.76 & 9.35 & 2.21 \\
\hline Mining and Quarrying & 3.33 & 1.73 & 8.11 & 0.71 & 4.96 \\
\hline $\begin{array}{l}\text { Electric Power, Steam, Hot } \\
\text { Water }\end{array}$ & 1.68 & 0.00 & 0.00 & 0.45 & 0.00 \\
\hline $\begin{array}{l}\text { Coking,Gas and Petrol } \\
\text { Refining }\end{array}$ & 1.20 & 0.97 & 2.58 & 0.71 & 2.72 \\
\hline Foodstuff & 3.64 & 4.01 & 2.95 & 1.11 & 6.36 \\
\hline Textile, Sewing, Leather & 4.08 & 19.22 & 5.74 & 1.27 & 26.09 \\
\hline Chemical Industry & 4.04 & 8.27 & 13.67 & 1.04 & 8.89 \\
\hline $\begin{array}{l}\text { Building Materials and NM } \\
\text { Mineral Products }\end{array}$ & 1.95 & 1.70 & 1.18 & 1.75 & 6.27 \\
\hline Metal Products & 2.75 & 6.25 & 10.43 & 1.29 & 9.22 \\
\hline Machinery and Equipment & 8.95 & 35.16 & 41.17 & 1.15 & 19.59 \\
\hline Other Manufacturing & 2.35 & 5.63 & 6.11 & 0.79 & 14.64 \\
\hline Construction & 7.82 & 0.11 & 0.21 & 2.62 & 0.11 \\
\hline Transport, Post, Telecom & 4.52 & 3.28 & 0.80 & 0.79 & 7.20 \\
\hline $\begin{array}{l}\text { Commerce and Catering } \\
\text { Trade }\end{array}$ & 8.05 & 6.46 & 0.35 & 2.71 & 8.85 \\
\hline $\begin{array}{l}\text { Public Utilities and Resident } \\
\text { Services }\end{array}$ & 4.74 & 4.33 & 2.65 & 1.06 & 9.09 \\
\hline Banking and Insurance & 3.11 & 0.07 & 1.04 & 1.48 & 0.30 \\
\hline Other Services & 10.86 & 0.29 & 0.25 & 4.27 & 0.46 \\
\hline Total & 100 & 100 & 100 & 1.72 & 9.01 \\
\hline
\end{tabular}

Source: Author's calculation based on 2000 Input-Output Table, China Statistical Yearbook 2004. 
Table 2: Sectoral ElasticityValues

\begin{tabular}{|c|c|c|c|c|}
\hline Sector & $\begin{array}{l}\text { Armington } \\
\text { Elasticity }\end{array}$ & $\begin{array}{c}\text { Income } \\
\text { Elasticity } \\
\text { of } C_{i}\end{array}$ & $\begin{array}{c}\text { Factor } \\
\text { Substitution } \\
\text { Elasticity }\end{array}$ & $\begin{array}{c}\text { Own-Price } \\
\text { Elasticity } \\
\text { of } C_{i}\end{array}$ \\
\hline Agriculture & 2.2 & 0.23 & 0.24 & -0.40 \\
\hline Mining and Quarrying & 2.8 & 1.23 & 0.20 & -1.40 \\
\hline $\begin{array}{l}\text { Electric Power, Steam, Hot } \\
\text { Water }\end{array}$ & 2.8 & 1.23 & 1.26 & -1.39 \\
\hline $\begin{array}{l}\text { Coking,Gas and Petrol } \\
\text { Refining }\end{array}$ & 1.9 & 1.12 & 1.26 & -1.27 \\
\hline Foodstuff & 2.2 & 0.80 & 1.12 & -0.92 \\
\hline Textile, Sewing, Leather & 4.0 & 0.96 & 1.26 & -1.08 \\
\hline Chemical Industry & 1.9 & 1.23 & 1.26 & -1.38 \\
\hline $\begin{array}{l}\text { Building Materials and NM } \\
\text { Mineral Products }\end{array}$ & 1.9 & 1.23 & 1.40 & -1.39 \\
\hline Metal Products & 2.8 & 1.23 & 1.26 & -1.39 \\
\hline Machinery and Equipment & 3.0 & 1.01 & 1.26 & -1.13 \\
\hline Other Manufacturing & 2.8 & 1.01 & 1.26 & -1.14 \\
\hline Construction & 1.9 & 1.23 & 1.40 & - \\
\hline Transport, Post, Telecom & 1.9 & 1.29 & 1.68 & -1.44 \\
\hline $\begin{array}{l}\text { Commerce and Catering } \\
\text { Trade }\end{array}$ & 1.9 & 1.29 & 1.26 & -1.41 \\
\hline $\begin{array}{l}\text { Public Utilities and Resident } \\
\text { Services }\end{array}$ & 1.9 & 1.23 & 1.26 & -1.36 \\
\hline Banking and Insurance & 1.9 & 1.29 & 1.26 & -1.44 \\
\hline Other Services & 1.9 & 1.29 & 1.26 & -1.42 \\
\hline
\end{tabular}

\section{Simulation Analysis}

As noted above, Goldstein (2004) suggests that a drop of the current-account/Y ratio by around 4 percentage points is required to re-establish current balance-of-payments equilibrium. The model does not explicitly capture international transfer and net factor income flows, yet Chart 1 shows that the current account is dominated by the trade balance TB. Hence we shock the model to generate an endogenous 4 percentage-point drop in the $\mathrm{TB} / \mathrm{Y}$ ratio. Since the behavioural relations in the model are based on neoclassical microfoundations, the model is zero-homogeneous in prices including e and 
only relative prices matter. The setting is by design not meant to predict the potential short-run macroeconomic effects of a nominal devaluation. Comparative-static simulations using this type of non-monetary model are in conception comparisons of stationary "long-run" equilibria in which the classical dichotomy is supposed to hold. ${ }^{11}$ To generate the envisaged current account (CA) balance reduction, a revaluation must be associated with a rise in domestic absorption $\mathrm{A}$ relative to income $\mathrm{Y}$, or stated equivalently with a drop in total savings $\mathrm{SH}$ relative to aggregate investment INV, since in a national accounting sense

$\mathrm{CA}=\mathrm{Y}-\mathrm{A}=\mathrm{SH}-\mathrm{INV} \quad \Rightarrow \mathrm{CA} / \mathrm{Y}=1-\mathrm{A} / \mathrm{Y}=\mathrm{s}-\mathrm{INV} / \mathrm{Y}$, where $\mathrm{A}=\mathrm{CH}+\mathrm{G}+\mathrm{INV}$ is total domestic final expenditure on home goods and imported goods. Now recall from (16) that $S H=s Y=G D+I N V+T B$, i.e. new savings are essentially used to purchase new government debt instruments, to finance real investment, and - under the present regime of sterilized foreign intervention and strict controls on capital outflows - to buy sterilization instruments issued by the central bank to neutralize the money supply effects of its foreign exchange interventions. Once the PBOC stops or reduces its intervention activity to allow a revaluation, the supply of sterilization bonds shrinks. Savings that would have gone into these bonds in the status quo ante are redirected to government bonds and real investment. As a result, the rate of return on bonds and the cost of capital drop. So the investment rate rises while the saving rate shrinks. This stylized macroeconomic mechanism provides the rationale for the approach used here to generate a real exchange rate revaluation that reduces the trade balance by 4 percent of benchmark GDP within the present model. The revaluation shock is induced by a drop in TBW in combination with a simultaneous drop in s, so that the fraction of income previously used to buy sterilization bonds (or foreign assets not eventually converted into such bonds) is distributed equally between INV and $\mathrm{CH}){ }^{\mathbf{1 2}}$

Table 3 summarizes the main macroeconomic effects of this policy shock under two alternative labour market closures. The first closure assumes a fixed labour endowment and endogenous market-clearing wage adjustment, while the second closure supposes

\footnotetext{
${ }^{11}$ If one chooses the foreign reserve asset as the numeraire and rescales its domestic currency price e, all nominal magnitudes in the model would plainly change in proportion with zero real effects.

${ }^{12}$ To be precise, $\mathrm{s}$ drops from $\left(\mathrm{GD}_{0}+\mathrm{INV}_{0}+\mathrm{TB}_{0}\right) / \mathrm{Y}_{0}$ to $\left(\mathrm{GD}_{0}+\mathrm{INV}_{0}+0.5 \mathrm{~TB}_{0}\right) / \mathrm{Y}_{0}$ where the 0 subscript refers to benchmark levels.
} 
unlimited supplies of labour with an exogenously fixed real wage in terms of the consumer price index. In both cases, the terms-of-trade improvement associated with the simulated trade balance reduction is slightly more than 4 percent $^{13}$, while China's aggregate real exports drop by around 11 percent, and the aggregate import volume rises by 10 to 13 percent vis-à-vis the benchmark equilibrium. The labour displacement ratio in Table 3 is defined as

$$
\text { Labour Displacement Ratio }=100 \cdot \frac{1}{2 L_{o}} \sum_{i \in I}\left|L_{i}-L_{o, i}\right|,
$$

where the subscript o refers to benchmark employment levels. It measures the percentage of the benchmark labour force in recorded employment that is intersectorally relocated due to the revaluation shock. In the model, intersectoral factor movements are frictionless and labour adjustment costs are neglected. Provided that intrasectoral labour movements not captured by the model under the given aggregation structure are in fact associated with significantly lower adjustment costs than intersectoral movements, the ratio may be seen as a rough indicator of the fraction of total employment directly affected by such adjustment costs. In absolute terms, the labour displacement ratio of 0.93 percent for the fixed labour endowment closure amounts to the intersectoral relocation of 65 million "average productivity workers".

\section{Table 3: Aggregate Effects of a Revaluation}

\begin{tabular}{l|ll}
\hline \% Change in & Fixed Labour Supply & Unlimited Labour Supply \\
\hline Terms of Trade & +4.2 & +4.3 \\
Real Exports & -10.7 & -11.0 \\
Real Imports & +10.5 & +13.6 \\
Real Consumption & +5.1 & +7.4 \\
Investment/ GDP ratio & +2.1 & +2.9 \\
Real GDP & +0.0 & +2.1 \\
Real Wage (w/CPI) & +1.2 & - \\
Labour Displacement Ratio & 0.93 & 1.81 \\
Employment & - & +3.2 \\
\hline
\end{tabular}

\footnotetext{
${ }^{13}$ As a matter of course (see e,g. Willenbockel (2004) for a recent elaboration), the size of the terms-oftrade effects in any model with international product differentiation is in particular sensitive to the selection of Armington elasticities of substitution. The elasticity figures used here as reported in Table 1 are 'consensus' estimates widely employed in CGE trade policy studies. See Gilbert and Wahl (2002) for a recent survey of CGE studies addressing China's accession to the WTO.
} 
Table 4 reports the sectoral employment and trade effects for the two scenarios. The strongest negative employment effect occurs not too surprisingly in the Textile, Sewing and Leather sector, which is also the sector with the strongest reduction in exports and the highest initial export-output ratio. Machinery and Equipment, the sector with the highest share in total exports and the second-highest benchmark export-output ratio likewise shrinks. Other manufacturing sectors with negative employment effects are Chemicals, Metal Products and Other Manufacturing, while employment rises primarily in the almost non-traded service sectors and Construction.

The aggregate expansionary employment effect under the elastic labour supply closure deserves further comment, given that opponents of a major RMB revaluation emphasize the danger of a deflationary effect for the Chinese economy. Yet the common association of a revaluation with a contractionary aggregate employment effect is based on a standard Mundell-Fleming-style short-run fix-price analysis with a fixed saving rate, while the present analysis takes long-run general equilibrium price effects into account and furthermore assumes that, as explained above, the drop in sterilized intervention activity must be associated with a drop in household savings and a rise in domestic investment demand. ${ }^{14}$

\footnotetext{
${ }^{14}$ Recall that without these latter assumptions, a nominal revaluation would have no real long-run effects at all in the present general equilibrium framework.
} 
Table 4: Sectoral Employment and Trade Effects

\begin{tabular}{|c|c|c|c|c|c|c|}
\hline \multirow[b]{2}{*}{ Sector } & \multicolumn{3}{|c|}{ Fixed Labour Supply } & \multicolumn{3}{|c|}{ Unlimited Supply of Labour } \\
\hline & \begin{tabular}{|} 
Employment \\
$\%$
\end{tabular} & $\begin{array}{c}\text { Exports } \\
\%\end{array}$ & $\begin{array}{c}\text { Imports } \\
\%\end{array}$ & $\begin{array}{c}\text { Employment } \\
\%\end{array}$ & $\begin{array}{c}\text { Exports } \\
\%\end{array}$ & $\begin{array}{c}\text { Imports } \\
\%\end{array}$ \\
\hline Agriculture & +0.3 & -10.2 & +12.1 & +2.1 & -8.9 & +12.2 \\
\hline Mining and Quarrying & -2.8 & -11.7 & +10.6 & -0.5 & -12.8 & +14.4 \\
\hline $\begin{array}{l}\text { Electric Power, Steam, Hot } \\
\text { Water }\end{array}$ & -1.0 & - & - & +4.0 & - & \\
\hline $\begin{array}{l}\text { Coking,Gas and Petrol } \\
\text { Refining }\end{array}$ & +0.0 & -7.2 & +8.6 & +5.0 & -7.9 & +12.1 \\
\hline Foodstuff & +1.3 & -9.8 & +13.6 & +5.1 & -9.4 & +15.4 \\
\hline Textile, Sewing, Leather & -6.8 & -15.0 & +14.0 & -4.2 & -15.0 & +15.9 \\
\hline Chemical Industry & -2.7 & -7.4 & +6.1 & +1.0 & -7.8 & +8.5 \\
\hline $\begin{array}{l}\text { Building Materials and NM } \\
\text { Mineral Products }\end{array}$ & +2.6 & -11.1 & +16.8 & +7.7 & -11.4 & +21.4 \\
\hline Metal Products & -2.8 & -10.3 & +9.8 & +1.2 & -10.9 & +13.3 \\
\hline Machinery and Equipment & -3.0 & -10.5 & $+11 . .1$ & +0.9 & -10.9 & +14.5 \\
\hline Other Manufacturing & -2.2 & -11.0 & +11.8 & +1.2 & -11.6 & +14.8 \\
\hline Construction & +6.0 & -7.6 & +15.1 & +12.1 & -7.6 & +20.2 \\
\hline Transport, Post, Telecom & +0.4 & -7.9 & +10.5 & +5.8 & -8.6 & +14.0 \\
\hline $\begin{array}{l}\text { Commerce and Catering } \\
\text { Trade }\end{array}$ & +0.6 & -8.2 & +10.9 & +4.2 & -8.0 & +13.4 \\
\hline $\begin{array}{l}\text { Public Utilities and Resident } \\
\text { Services }\end{array}$ & +1.0 & -8.1 & +11.3 & +5.1 & -8.4 & +14.2 \\
\hline Banking and Insurance & +1.0 & -8.7 & +11.1 & +5.2 & -8.8 & +13.9 \\
\hline Other Services & +1.1 & -8.4 & +10.6 & +2.8 & -8.0 & +11.0 \\
\hline Total & 0 & -10.7 & +10.5 & +3.2 & -11.0 & +13.6 \\
\hline
\end{tabular}

\section{Concluding Remarks}

In a nutshell, the preceding stylized simulation analysis suggests that a drop in China's trade balance by four percent of GDP in order to restore China's external balance to a sustainable level, would be associated with fairly moderate intersectoral employment relocation effects. To the extent that the drop in the supply of sterilization bonds implied 
by a revaluation leads to a drop in domestic interest rates that stimulates household spending and investment, aggregate employment may actually rise in the presence of surplus labour that allows employment expansion at an unchanged real wage. To keep a proper sense of perspective on these results from a highly stylized flex-price general equilibrium model, a number of qualifying remarks are in order. The model assumes instantaneous price adjustments and frictionless intersectoral factor movements. With sluggish domestic price adjustments to an initial nominal revaluation shock, aggregate employment would initially contract on impact, and the comparative-static long-run analysis is based on the implicit assumption that such short-run impacts do not generate hysteresis effects. Due to its static nature, the saving-investment closure of the model is necessarily ad hoc, and the analysis cannot take account of potential foregone learningby-doing effects in the contracting manufacturing export sectors. In the light of these caveats it might indeed be advisable to combine a major RMB alignment with active policy measures that would lead to a reduction in China's exorbitantly high saving rate and simultaneously support the shifts in employment from manufacturing to services along the lines suggested by Blanchard and Giavazzi (2005). 


\section{References}

Blanchard, O., Giavazzi, F. (2005) Rebalancing Growth in China: A Three-Handed Approach. MIT Department of Economics Working Paper 05-32, MIT: Cambridge, MA.

Chang, G.H., Shao, Q. (2004) How Much is the Chinese Currency Undervalued? A Quantitative Estimation. China Economic Review 15, 366-371.

Dimaranan, B., McDougall, R., Hertel, T. (2002) Global Trade, Assistance, and Production: The GTAP 5 Data Base. Center for Global Trade Analysis, Purdue University: West Lafayette.

Dooley, M., Folkerts-Landau, D., Garber, P. (2003) An Essay on the Revived Bretton Woods System. NBER Working Paper No.9971, National Bureau of Economic Research: Cambridge.

Dooley, M., Garber, P. (2005) Is it 1958 or 1968 ? Three Notes on the Longevity of the Revised Bretton Woods System. Brookings Papers on Economic Activity No.1:2005, 147-xxx.

Funke, M., Rahn, J. (2004) Just How Undervalued is the Chinese Renminbi? BOFIT Discussion Paper No.14/2004. Bank of Finland: Helsinki.

Funke, M., Rahn, J. (2005) Just How Undervalued is the Chinese Renminbi? The World Economy 28(4), 465-489.

Gilbert, J., Wahl, T. (2002) Applied General Equilibrium Assessments of Trade Liberalisation in China. The World Economy 25, 697-731.

Goldstein, M. (2004) Adjusting China's Exchange Rate Policies. Institute for International Economics Working Paper No.04-1, IIE: Washington, D.C.

Goldstein, M., Lardy, N.R. (2005b) China's Role in the Revised Bretton Woods System: A Case of Mistaken Identity. Institute for International Economics Working Paper No.05-2, IIE: Washington, D.C.

Goldstein, M., Lardy, N.R. (2005a) China's Revaluation Shows Size Really Matters. Financial Times, July 22.

Huang, H., Wang, S. (2004) Exchange Rate Regimes: China's Experience and Choices. China Economic Review 15, 336-342

Huff, K.M., Hanslow, K., Hertel, T.W., Tsigas, M.E. (1997) GTAP Behavioral Parameters. T.W. Hertel (ed) Global Trade Analysis: Modeling and Applications. Cambridge University Press: Cambridge, 124-148. 
Spiegel, M.M. (2005) A Look at China's New Exchange Rate Regime. FRBSF Economic Letter 23-2005, September 9.

Sun, H., Ma, Y. (2005) Policy Strategies to Deal with Revaluation Pressures on the Renminbi. China Economic Review 16, 103-117.

Tung, C.-Y., Baker, S. (2004) RMB Revaluation Will Serve China's Self Interest. China Economic Review 15, 331-335.

Willenbockel, D. (1994) Applied General Equilibrium Modelling: Imperfect Competition and European Integration. Wiley: Chichester.

Willenbockel, D. (2004) Specification Choice and Robustness in CGE Trade Policy with Imperfect Competition. Economic Modelling 21, 1065-1099.

Zhang, F., Pan, Z. (2004) Determination of China's Long-Run Nominal Exchange Rate and Official Intervention. China Economic Review 15, 360-365.

Zhang, Z. (2001) Real Exchange Rate Misalignment in China: An Empirical Investigation. Journal of Comparative Economics 29, 80-94. 